\title{
Global Responsibility in a Historical Context
}

\begin{abstract}
Contemporary theories of globalization seldom mention history. This is surprising, because 'globalization' is essentially a historical term, describing as it does a historical process. There is less mention still of the philosophy of history, especially given that it has been discredited. And yet, if one probes the accounts in question more deeply, there is no overlooking that nearly all of the relevant discourses operate more or less explicitly with patterns of interpretation borrowed from the philosophy of history. The authors speculate upon which general tendencies of globalization are recognizable, and whether it is more indicative of 'progress' or of the 'downfall' of human civilization. Moreover, the questions of when globalization actually began, what is 'new' about the state of globality achieved thus far and what developments can be expected in future cannot possibly be answered without reflecting on history. After all, the ethical problem of global justice, which demands compensatory measures to alleviate historic harms, requires us to take into account the course of history thus far. Such topics underline that recourse to history, with all of its historico-philosophical implications, is essential if we are to resolve the problems resulting from globalization.
\end{abstract}

\section{Globalization and history}

Considering the phenomenon of globalization from a philosophical viewpoint, one must first note that the global has always been a theme in philosophy (Figuera 2004, p. 9; cf. Negt 2001, pp. 42; Toulmin 1994, p. 281). The search for universal concepts and principles that could claim validity for all of humankind is part of the philosophical tradition. From the (early) modern period onward, philosophically grounded human rights were intended to apply to all of the earth's inhabitants equally and universally. In particular, the history of philosophy as it has developed since the Enlightenment proclaimed the existence of a universal or world history in which all peoples and cultures participate (Rohbeck 2010, p. 54; Brauer 2012, p. 19; Roldán 2012, pp. 83-84). This also applies to subsequent philosophies of history that distanced themselves from the ideas of prog-

Johannes Rohbeck, Technische Universität Dresden (TUD)

Ә OpenAccess. (C) 2018 Johannes Rohbeck, published by De Gruyter. (cc) BY-NC-ND This work is licensed under the Creative Commons Attribution-NonCommercial-NoDerivatives 4.0 License. 
ress and teleology, and even to the later position of posthistoire, which posits the 'end' of history.

Contemporary theories of globalization seldom mention history. There is less mention still of the philosophy of history, especially given that it has been discredited. And yet, if one probes the accounts in question more deeply, there is no overlooking that nearly all of the relevant discourses operate more or less explicitly with patterns of interpretation borrowed from the philosophy of history. The authors speculate upon which general tendencies of globalization are recognizable, and whether it is more indicative of 'progress' or of the 'downfall' of human civilization (Scholte 2005, p. 49; versus Hardt / Negri 2003, p. 296; Kehoane / Joseph 2005, p. 76; Baudrillard 2007, p. 22; Groß 2007, p. 16). This shows that globalization is largely understood as a historical process. The very questions of when globalization actually began, what is 'new' about the state of globality achieved thus far, and what developments can be expected in future cannot possibly be answered without reflecting upon history.

This global history perspective in turn changes the way history is viewed. In traditional theories of history, the focus was on historical time, whose concepts and structures the authors explored (Koselleck 1979/2004; Ricœur 1984). History was equated with 'temporalization', and corresponding studies focused on historical times with their continuities and ruptures, as well as changes in the tempo of history such as stagnation and acceleration. In the context of globalization, the focus is increasingly on historical spaces, so that history is not merely 'temporalized' but also 'spatialized' (Osterhammel 1998, p. 374; Schlögel 2003, pp. 12-13). When we analyze how economic, political, social and cultural spaces are created with time, history comes to appear as a spatial-temporal construct.

My thesis is that the ethics of globalization, too, could benefit from the reflections of historiography and the philosophy of history. For there can be no doubt that catastrophic climate change and global poverty, which are to some degree connected, were 'made' by human beings in the course of their history. From this we may draw the ethical conclusion that the harms caused should be rectified through compensatory measures. The current debate over such measures shows what a central role the treatment of history plays. Those who generally reject the industrial nations' moral duty towards the poor countries already consider the historical context to be irrelevant. But even those who believe that rich countries have an obligation to help make their arguments independent of history. A farther-reaching responsibility that includes compensation for the effects of harmful behavior, in contrast, can only be justified with reference to the course of history thus far. For that reason, I call this type of responsibility 'historical responsibility'. It follows, in turn, that the recourse to history, with all of 
its historico-philosophical implications, is indispensable for a resolution of the problems resulting from globalization.

\section{Historical responsibility}

Leaving aside extreme libertarian and nationalist positions, there is a consensus that people living in rich countries have an obligation to help the needy in poor countries. This expressly also applies to states on a global scale. To be sure, one can distinguish between certain degrees of remedial responsibility, allowing for special obligations towards members of one's own family or nation, which produces a graduated conception of justice (Walzer 1999, p. 38; Zurbuchen 2005, p. 139; Nida-Rümelin / Rechenauer 2009, p. 314, 319). It does not follow, however, that there is no basis for farther-reaching obligations towards people who live in distant parts of the world. The objection that such a redistribution of goods from rich to poor countries presupposes a 'world state', with all its potential for abuses (Nusser 1997, p. 92), is also not convincing, because, as was explained, individual states and transatlantic organizations are also in a position to do this.

Nevertheless, we need to ask why people are obligated to help other people. Opinions on this question differ: on the one side, we have the position of socalled remedial duties, based on the argument that human beings as such are obliged to help others to the extent that they are able (Previous cooperation or even historic connections between these people expressly play no role here.); and on the other side, we find the position of outcome responsibility, which assumes that the plight of individuals in poor countries should be viewed as the 'consequence' of acts performed by the inhabitants of rich or powerful countries (At this point the historical aspect comes into play, for such an outcome responsibility is, after all, rooted in a historical process that led to great injustices in the past.). I propose that global responsibility for unjustly treated people and peoples is, in turn, in need of both historical and historico-philosophical reflection.

If one examines the argumentation on remedial duties more closely, its position on history appears paradoxical. One argument is that human suffering and death is something fundamentally bad that needs to be overcome in all cases, without creating a practical-historical relationship between the givers and seekers of assistance (Singer 2007, p. 39; Schlothfeld 2007, p. 77; Schaber 2007, p. 139). Those with a duty to assist function merely as witnesses capable of helping, who observe the needy from afar. Because what is at stake is ultimately an anthropological principle (and thus the unity of the human species, which has a duty to assist) this is a case of abstract cosmopolitanism. The meta-ethical approach of universalist morality, which calls for general assent to the moral norm of reme- 
dial measures from an impartial perspective, offers a similar argument (Birnbacher 2007, p. 139). According to this approach, the global moral community assumes responsibility, as efficiently as possible, for the well-being of all human beings, whose standard of living must not fall below the minimum subsistence level.

A further argument states that people are obligated to prevent or alleviate suffering, whatever its origins, as far as possible. The pragmatic boundary consists in limiting remedial duties to preventing the bad rather than promoting the good, so as to demand no excessive sacrifices. Repressed history reappears in this argument; for the power to assist even distant people is largely dependent on the technological means of communication and transport as they have evolved (Singer 2007, p. 40). It is therein that the real conditions for the possibility of global remedial duties exist. And because these conditions change over the course of history, the position of the remedial duty assumes an unanticipated historical dimension. In contrast to traditional ethics, which was limited to the narrow circles of family, region or nation-state, a new ethics of global remedial duty is emerging.

Reversing this argumentation, one could also formulate it as follows: because people have access to novel technological means for assisting very distant people, they should do so. To the extent that one assumes that the alleviation of suffering is desirable in general, this entails no naturalistic fallacy, but it does imply recognition that the new technological instruments create new moral aims or historically conditioned norms, which amounts to a technologically mediated transformation of values. Thus, from this position, the historical refers not to the previous history of the sufferer's plight, but rather to the historically evolved power of the helper.

The second position of outcome responsibility raises the question of whether the argument of pure remedial duties is sufficient, and whether farther-reaching duties cannot be justified.

On the side of the helpers, the problem already exists in the subjects who are obligated to assist. The impression arises here that it is primarily individuals who decide to provide assistance without any previous agreement. Moreover, there is no social differentiation among the affluent or assignment to social systems. One could object that collective actors have far greater significance in global aid actions. Even an appeal for donations to which individuals spontaneously respond represents a coordinated action (Schlothfeldt 2007, p. 77). This applies all the more to states and trans-state organizations, which take action as social institutions.

On the side of those requiring assistance, the problem is that the needy appear solely as victims. They remain passive and anonymous sufferers (moral 
strangers), to whom no particular relationship of responsibility exists (Birnbacher 2007, p. 132). They figure as mere objects of a donation, which therefore risks becoming authoritarian and arbitrary. It is striking above all that while this assigns particular obligations to the wealthy, it accords no rights to the poor. Duties are thus accompanied by no rights that could be asserted in the form of legitimate demands. There is in fact no preceding interaction between givers and takers. This also cancels all criteria of commutative justice.

If, however, one insists that the poor have certain rights beyond universal human rights, one is referred to concrete contexts associated with the social imbalance that stands to be remedied or alleviated. People frequently speak of cooperation here, which can establish a global obligation (Nida-Rümelin / Rechenauer 2009, p. 316). Those who baulk at referring to interactions with the poor as cooperation (Birnbacher 2007, p. 135) can speak neutrally of an action context that precisely encompasses discrimination against foreign peoples, including their exploitation. Positive or negative cooperation forms the basis of rich, industrialized nations' moral responsibility towards poor, developing countries.

This relationship yields obligations that extend beyond mere remedial duties. To be sure, wealthy citizens and states have the positive moral obligation to assist people in conditions of life-threatening poverty. At the same time, however, they have the negative obligation to minimize the harms they cause (Pogge 2003, p. 243). Because the world order is not just, the poor must be compensated for the disadvantages they suffer. Such compensation is not aid, but the lessening of harm; it is not redistribution from the rich to the poor, but a corrective to an unjust social structure between poor and rich. Not helping the disadvantaged is less reprehensible than denying them justified profits by exploiting their disadvantaged condition (Pogge 2003, p. 244).

This conception of outcome responsibility, however, has historical implications-so I would like to speak of a historical responsibility; for behind this argument is the recognition that world poverty is the consequence of an historical process, which since colonialization has included enslavement, genocide, and exploitation (Pogge 2003, p. 222). To limit oneself, in contrast, to mere assistance, is to overlook the roots of the West's enormous economic superiority over centuries of common history that devastated four continents (Nida-Rümelin / Rechenauer 2009, p. 300). The great majority of property rights came about in an unacceptable manner, through violence, conquest and oppression. From this derives the call to demand farther-reaching duties to compensate for the injustices suffered. The legal principle of fault-based liability applies here: those who actively cause distress are responsible for alleviating it, for the creation of an evil generates a particularly high degree of responsibility. 
A number of objections have been raised to the historical argument in particular. The scope of the duty to compensate is allegedly limited. On the one hand, it presupposes that the previous harms are actually demonstrable. On the other, it must be proven that past damages continue to affect the present. The first objection states that present-day governments in the developing countries are as much to blame for current poverty as past colonialists. Moreover, the duty to compensate for harmful behavior applies only to those states that actually participated in the injustices committed at an earlier time (Birnbacher 2007, p. 136). Finally, there is the problem of moral subjects, if one holds only individuals and not collective actors accountable.

A particularly widespread objection cites so-called internal causes, stating that the essential factors for global poverty should be sought within presentday developing countries and thus in domestic difficulties. This objection seems to be underlined by the significant differences between the developing countries stemming from local factors, so that in the end the entirety of local factors were the cause of global poverty (quoted in Pogge 2003, p. 224, 229; Rawls 2002, p. 134; Nagel 2005, p. 123). This appears to be confirmed by the frequency of brutal and corrupt regimes in developing countries today. By implication, the successes of some developing and newly industrialized countries seem to demonstrate that the harmful effects of past colonialization have since faded. Aside from the fact that the thesis of 'internal causes' serves as an excuse for the rich countries, this impression is also the product not least of historians' and sociologists' tendency to focus more on national and regional factors than on worldwide developments.

Conversely, the duty to compensate is justified by the fact that local circumstances cannot adequately account for global poverty. The world economic order, with all its inequities, remains responsible for the failure to thrive of economies in developing countries. Thus, even with continuous economic growth, Africa today has no chance of catching up with Europe's lead of 30 to 1. Given this massive advantage, current inequality is not simply the effect of free choice. In addition, so-called domestic factors are themselves conditioned by the global order, because the current world order contributes significantly to corruption and oppression in developing countries (Pogge 2003, p. 233). This includes the international resource privilege, the disequilibrium between rich natural resources and economic growth, as well as dependence on the global realm (Pogge 2003, p. 235; Kesselring 2005, p. 48). The consequence is that it is not merely a matter of distributing goods fairly, but above all also of eliminating unfair conditions of production.

If nothing else, we need to repudiate the fallacy that the duty to compensate calls remedial responsibilities into question, as if the two types of duties were 
mutually exclusive. Naturally all rich countries have a duty to help, even if they feel no guilt, or do not accept the concept of outcome responsibility. But according to the farther-reaching argument, those states that were involved in past harm have a particular duty to compensate in the present.

The whole debate underlines how essential the historical aspect is. After all, it rests on the elementary insight that global poverty was 'made' by certain people in the course of history. And ultimately, it is precisely this manner of 'making' history that is subject to debate. Even historical details about which global and local factors should be weighted to what extent and with which spatial and temporal scope play a role here. This harnesses the entire arsenal of historical research, down to methodological questions about the explanatory function of certain data. Even the method of counterfactual explanation comes into play, for example in discussions of whether people in developing countries are better off today than they would have been had they persisted in a fictional state of nature, and had colonialization processes never taken place (Pogge 2003, p. 237).

Finally, there is the pragmatic question of to what extent referring to the past produces quantifiable compensatory measures. With respect to actual assistance, it is far removed from any practical dimension where the theoretical distinction between remedial and outcome responsibilities might play a role. But in fact, the historical aspect is important in the discourses because it leads to payments that, while not truly compensations, can still be understood as partial acknowledgements of injustices suffered. This is clearly connected with the intention to heighten awareness of specifically historical responsibility. Even if such an argument is not directly reflected in appropriate figures, it can contribute to doing more for the poor countries than strictly required in a given situation. Above all, the historical argument calls upon us not just to alleviate suffering, but also to attack its causes by promoting a more just world than the one that has evolved over the course of history. This presents us with the task of seeking alternative possibilities for global developments in the future.

\section{Conclusion}

The problem with most ethics devoted to the problem of global poverty is that they are conceived without reference to history. This lack of history represents a double difficulty. On the one hand, universal principles provide no sufficient argument for the remedial duties invoked. On the other, these principles remain so abstract that it is impossible to differentiate both those who need help and those who have a duty to provide it. The fight against global poverty should not be mistaken for universalism. Rather, to assume the global ethical stand- 
point is to analyze the historical process of globalization, and to derive concrete and differentiated responsibilities from the conditions in which global poverty arises.

As we have seen, the globalization process takes place in diverse historical spaces and times. In the field of the world economy, this means envisioning the new spatial economy of capitalism with the development of natural resources, the increase in sales markets, and the search for favorable conditions of production in distant lands. While it is legitimate to point to local factors as well when making international comparisons, this should not tempt us to underestimate the influence of the world economic system. In the political arena, this means that the role of nation-states needs differentiation. This also applies in particular to developing countries, which were and still are dependent in specific ways on the old colonial powers. Thus, if one points to the inadequacies of these states in order to shift the blame for global poverty onto them, one should equally recall that these domestic deficiencies are also conditioned by the global order. In order to overcome hardship, associations of states are increasingly emerging within the groups of developing and newly industrialized countries that fulfill a similar function to the European Union. In these cases, too, the national and transnational levels overlap to form a supra-territorial space-time structure. It is precisely these new assemblages that require special support from the old industrial nations.

Thus when we consider the history of globalization, we no longer need only to enquire into the historical beginnings of the process, but also to determine more precisely where and when to seek the roots of global poverty. If this question is in the foreground, we can surely place the beginning of globalization earlier-if not already in the earliest phases of colonialization from the sixteenth to the eighteenth centuries, then at least in nineteenth-century colonialism. And if we declare the emergence of electronic networks in the twentieth century as the birth of modern globalization, we need to ask to what degree these networks promote or hinder development in the poor countries. There is no question that this development, too, disadvantages or excludes entire regions.

Finally, addressing the long-term effects of these developments on living conditions in poor countries raises the historico-philosophical question of the continuities and discontinuities in the globalization process. It makes sense that postulating historical responsibility is possible only if one assumes a minimum of historical continuity, for those who treat the ruptures in the globalization process as absolute run the risk of underestimating their long-term effects and playing into the hands of those who deny any historical responsibility. Adhering to sustained development in no way means naively believing in a linear process of modernization, let alone in homogeneous progress. Affirming a histo- 
ry with shared responsibility is perfectly compatible with criticism of the downsides of the course taken by history. Ultimately, the struggle against global poverty presupposes a conviction that living conditions can be improved in the long term. The world's poor are not the only ones who consider such improvements 'progress'. An ethics of global responsibility is quite inconceivable without this regulative idea. These considerations show the fundamental nature of historical patterns of interpretation, and demonstrate just how indispensable historical and historico-philosophical reflections on globalization are.

\section{Bibliography}

Baudrillard, Jean (2004): "From the Universal to the Singular. The Violence of the Global”. In: Bindé, Jérôme (Ed.): The Future of Values. $21^{\text {st }}$-Century Talks. Translated by John Corbett. New York, Oxford, Paris: Berghahn, pp. 19-24.

Belvedresi, Rosa E. (2012): "Global History and the Idea of Universal History". In: Brauer, Daniel / D’Aprile, Iwan / Lottes, Günther / Roldán, Concha (Eds.): New Perspectives in Global History. Hannover: Wehrhahn, pp. 63-70.

Birnbacher, Dieter (2007): “Die ethischen Grundlagen globaler Hilfspflichten”. In: Schüttauf, Konrad / Brudermüller, Gerd (Eds.): Globalisierung-Probleme einer neuen Weltordnung. Vol. 7, Würzburg: Königshausen und Neumann, pp. 131-148.

Brauer, Daniel (2012): “Globalized History: Return to Weltgeist?" In: Brauer, Daniel / D’Aprile, Iwan / Lottes, Günther / Roldán, Concha (Eds.): New Perspectives in Global History. Hannover: Wehrhahn, pp. 19-30.

Figueroa, Dimas (2004): Philosophie und Globalisierung. Würzburg: Königshausen und Neumann.

Groß, Steffen W. (2007): “Kulturelle Mannigfaltigkeit und 'Globalisierung'. Heterogenität und Konnexion”. In: Schüttauf, Konrad / Brudermüller, Gerd (Eds.): Globalisierung-Probleme einer neuen Weltordnung. Würzburg: Königshausen und Neumann, pp. 11-28.

Hardt, Michael / Negri, Antonio (2001): Empire. Cambridge, (MA): Harvard University Press.

Keohane, Robert 0. / Nye, Joseph Jr. (2005): “Globalization: What's New? What's Not? (And So What?)". In: Held, David / McGrew, Anthony (Eds.): The Global Transformations Reader. An Introduction to the Globalization Debate. $2^{\text {nd }}$ ed., Cambridge (MA): Polity Press, pp. $75-83$.

Kesselring, Thomas (2005): “Internationale Gerechtigkeit. Auf der Suche nach Kriterien”. In: Angehrn, Emil / Baertschi, Bernard (Eds.): Globale Gerechtigkeit und Weltordnung. Justice globale et ordre mondial. Studia philosophica, Vol. 64, pp. 23-53.

Koselleck, Reinhart (1979/2004): Vergangene Zukunft. Zur Semantik geschichtlicher Zeiten. Frankfurt am Main: Suhrkamp.

Nagel, Thomas (2005): “The Problem of Global Justice”. In: Philosophy \& Public Affairs 33, No. 2, pp. 113-147.

Negt, Oskar (2001): Arbeit und menschliche Würde. Göttingen: Steidl Göttingen. 
Nida-Rümelin, Julian / Rechenauer, Martin (2009): “Internationale Gerechtigkeit”. In:

Ferdowsi, Mir A. (Ed.): Internationale Politik als Überlebensstrategie. Munich: Bayerische Landeszentrale für Politische Bildungsarbeit, pp. 297-321.

Nusser, Karl-Heinz (1997): “Kosmopolitische Vernunft und globale Weltordnung”. In:

Brieskorn, Norbert (Ed.): Globale Solidarität. Stuttgart: Kohlhammer, pp. 89-104

Osterhammel, Jürgen (1998): "Die Wiederkehr des Raumes: Geopolitik, Geohistorie und

historische Geographie”. In: Neue Politische Literatur 43, pp. 374-395.

Pogge, Thomas (2003): “'Armenhilfe' ins Ausland”. In: Analyse \& Kritik, 25, pp. 220-247

Rawls, John (1999): The Law of Peoples, Cambridge, (MA): Harvard University Press.

Ricœur, Paul (1984-1988): Time and Narrative. Translated by Kathleen McLaughlin and David Pellauer, 3 Vols., Chicago: University of Chicago Press.

Robertson, Roland (1992): Globalization: Social Theory and Global Culture. London: Sage.

Rohbeck, Johannes (2000): Technik-Kultur-Geschichte. Frankfurt am Main: Suhrkamp.

Rohbeck, Johannes (2010): Aufklärung und Geschichte. Berlin: Oldenbourg

Wissenschaftsverlag GmbH.

Roldán, Concha (2012): “Enlightenment, Philosophy of History and Values: European Roots of Universalism”. In: Brauer, Daniel / D’Aprile, Iwan / Lottes, Günther / Roldán, Concha (Eds.): New Perspectives in Global History. Hannover: Wehrhahn, pp. 83-96.

Schaber, Peter (2007): “Globale Hilfspflichten”. In: Bleich, Barbara / Schaber, Peter (Eds.): Weltarmut und Ethik. Paderborn: Mentis, pp. 139-151.

Schlögel, Karl (2003): Im Raume lesen wir die Zeit. Über Zivilisationsgeschichte und Geopolitik. Munich, Vienna: Hanser.

Schlothfeldt, Stephan (2007): “Wer ist der Weltarmut wozu verpflichtet?" In: Bleich, Barbara / Schaber, Peter (Eds.): Weltarmut und Ethik. Paderborn: Mentis, pp. 77-93.

Scholte, Jan Aart (2005): Globalization. A Critical Introduction. $2^{\text {nd }}$ ed., New York: Palgrave Macmillan.

Singer, Peter (1972): "Famine, Affluence and Morality”. In: Philosophy and Public Affairs, 1 No. 1, pp. 229-243.

Toulmin, Stephen (1994): Kosmopolis. Die unerkannten Aufgaben der Moderne. Frankfurt am Main: Suhrkamp.

Walzer, Michael (1990): “Zur Erfahrung von Universalität”. In: Kuschel, Karl-Josef / Pinzani, Alessandro / Zillinger, Martin (Eds.): Ein Ethos für eine Welt? Globalisierung als ethische Herausforderung. Frankfurt am Main, New York: Campus Verlag, pp. 38-47.

Zurbuchen, Simone (2005): “Globale Gerechtigkeit und das Problem der kulturellen Differenz -Eine kritische Auseinandersetzung mit dem liberalen Nationalismus”. In: Angehrn, Emil / Baertschi, Bernard (Eds.): Globale Gerechtigkeit und Weltordnung. Justice globale et ordre mondial. Studia philosophica, Vol. 64, pp. 121-141. 